\title{
Entrepreneurship Programs Should Nurture Companies of One
}

\author{
George Gendron (The Solo Project)
}

KEYWORDS: Educational Services, student entrepreneurs, Student innovators.

Either by circumstance or by choice, a growing number of entrepreneurs are working solo: running a company with themselves as the only employee. These soloists represent a huge opportunity for entrepreneurship schools to increase their impact. They just need to get past their preoccupation with nurturing the next Google or Facebook.

For every Larry Page or Michael Bloomberg, we can find millions of attorneys, software engineers, accountants, writers, business consultants and others who are ill prepared to manage the business end of their careers. Many of them simply want to do what they love on their own schedule and make a decent living at it, rather than a killing. Others might have toiled for some time in a corporate office before being downsized, finding themselves suddenly out on their own.

\section{Fastest-Growing Segment}

According to MBO Partners, a business services firm, the number of full-time independents (working 35 hours/week or more) rose $12.5 \%$ between 2011 and 2014 , to 17.9 million, compared to a $1.1 \%$ growth in the overall U.S. workforce. This sector of the economy will grow to 24.9 million workers by 2019. Another study, conducted by Intuit, estimated that by 2020 possibly more than $40 \%$ of the U.S. labor force could be independent workers.

For this fastest-growing segment of entrepreneurs, we need entrepreneurship programs that show them how to be successful. This means broadening the definition of "entrepreneurship" to include a startup company with only one employee. For more than 30 years, entrepreneurship programs in colleges and universities have focused on minting graduates for the world of the fast-growth, scalable startup company - firms that (if they're successful) could become the next Microsoft or Best Buy, employing tens of thousands. For example, Babson University has a "Founder's Fund," in which

students promise to give Babson, on average, $5 \%$ of equity in their as-yet-unformed companies. It's not hard to see the appeal of such a program. A wildly successful business adds much glamour and prestige to the school that incubated it. Many ambitious and talented students have flocked to these programs, attracted not only by courses, but also business plan competitions, accelerators, university-managed venture funds and formal mentorship programs.

But little evidence suggests that these programs are increasing the number of new companies. In fact, veteran university leaders in this space say most programs focus on helping entrepreneurial students scale up faster. That's a worthy goal, but another, much larger group of future entrepreneurs has been underserved: the millions of individuals who want, or will need, to run solo businesses.

\section{Why Soloing is Surging}

Consider that nearly half of attorneys now work for themselves, according to the American Bar Association. Membership in the Freelancer's Union, which provides health benefits for solo entrepreneurs, quadrupled since 2007. Entire industries have been reshaped in order to service this burgeoning market, including Best Buy's Geek Squad, UPS, "coworking" spaces and Staples' home delivery of office supplies. Technology platforms such as GoToMeeting and Basecamp have sprung up that give soloists the same videoconference and project management capabilities enjoyed by midsize to large companies. Linkedln and other social networks help them share ideas and connect with future clients or employers.

Why is the solo trend happening? One reason is that the nature of work has changed dramatically since the 1980s. The downsizing over the past 20 years has become permanent. Work opportunities no longer mean fulltime job opportunities. A company worth a lot of 
money does not always hire a lot of people; witness Instagram, which sold for $\$ 1$ billion but only had 13 employees.

Moreover, the concept of "employment" has become more fluid and the boundaries between salaried workers and soloists more permeable. Rather than adding fulltime jobs for a project, a company might put together a project team with contractors and soloists as well as salaried employees -- who in turn might strike out on their own and become contractors, rather than join another company. If you're not a salaried employee, it's up to you to figure out where you can fit in -- in short, to design your own job and your own relationship with the market for your services.

While the nature of "work" is changing, so are the attitudes of millions of talented professionals. Unlike their Baby Boomer parents, Millennials prefer to keep things simple. They will rent rather than buy, drive Zipcars instead of paying off car loans, and more often, value lifestyle over traditional measures of success. Baby Boomers, who've been successful at salaried jobs, often yearn for a lifestyle shift, leveraging their accomplishments and contacts to carve out work that is meaningful, profitable and independent. Even laid-off workers, much to their surprise, have come to find that they love the solo life, once they've adjusted and have built up a sustainable living. One study showed that all but $10 \%$ were eventually happier on their own.

Entrepreneurship schools can no longer afford to overlook these trends. Yet even the most celebrated entrepreneurship programs today look suspiciously at students who don't have an unrelenting focus on fast growth. At one school, which I won't name, a professor derided a 19-year-old who had started a $\$ 10$ million technology company with her brother, but didn't want to scale it up...she just wanted to do work that she enjoyed and continue to make money from it. "That's not a company," the professor scoffed. "It's a lifestyle."

In a b-school environment, the term "lifestyle business" is pejorative, implying a lack of ambition, drive and imagination. But increasingly, that's what a growing number of people want: a business that provides income; is a source of satisfying work; allows them to collaborate with peers they admire and respect; and gives them a greater degree of control over how, when, and where they work.

\section{Opportunities for Entrepreneurship Schools}

So what can business schools/entrepreneurship programs do to help them? For starters, they can broaden their concept of what it means to be employed, beyond the 1955 model of getting a job at a firm and working your way up the corporate ladder. They can also design programs for more students outside the entrepreneurship program - in pre-med, science, technology and all the liberal arts - to instill business literacy and practical skills so they can be prepared for self-employment, if desired, and thrive as soloists. Doing so will help schools groom more successful soloists; help more graduates be passionate about their work; and also help the schools themselves attract more students to the entrepreneurship and other programs.

Here are some specific ideas:

Teach entrepreneurship to everyone. Make it a university-wide requirement that all students take at least one course that immerses them in the worlds of entrepreneurship and innovation (how ordinary people accomplish extraordinary things, in business, the social sector or government). For those who want more depth, design a small cluster of courses that complement the above requirement as the nucleus of a concentration or minor.

Show students how to think. Create an undergraduate course for non-business students in "design thinking:" a skill that industrial designers use to frame problems and create products to solve them. Leaders in business, the non-profit realm and government have told me that too many graduates lack this skill - a shortcoming they say is more troublesome than poor communication skills. The class should include a lab that lets students design a prototype for an actual product and a feasibility study that explores the process of getting the concept to market or into the field.

Build basic financial literacy. Current generations of students have very little sense of money and value-of the hidden economic life of things, including family, church, government, education, etc. Some universities (Smith, for example) have developed informal, brownbag workshops that are voluntary; others are testing the concept of required workshops; a few are creating fullblown courses. All of these initiatives are designed to demystify finance. 
Create a project management course. An increasing percentage of all undergraduates in every major find themselves working in teams, and more of the work of every sector is project work. The early success of new organizations such as the Startup Institute shows that both recent grads and their prospective employers want and need these skills. Yet many universities do nothing to prepare students for rigorous teamwork. Working effectively in teams is a discipline; it is not intuitive or easy. Universities have a terrific opportunity to create a variety of formal and informal offerings that help students learn to assemble and lead a team; to create a realistic plan with clearly defined goals, milestones, and deliverables; and to understand overall team dynamics and dysfunctions.

Connect students and entrepreneurs. Create a monthly forum in which people starting projects and students looking to be part of a project can meet each other. The investment world offers numerous prototypes in which founders and potential investors are brought together, either formally or informally; the MIT Enterprise Forum is one notable example. Universities can also create and maintain databases of student projects toward the same end. Both live forums and a university-wide database of student projects can be very effective tools to recruit prospective students to campus.

\section{A New Approach}

Students must re-think how they approach school and work as well. They must commit to getting the vital business skills they need to succeed as a soloist, even if they plan to work at a traditional firm first. Working at a firm upon graduation should be approached as an opportunity to gain technical skills, develop good work habits and gather valuable contacts, all of which will prepare them to be on their own.

The self-employment economy is here to stay. The smart entrepreneurship schools will expand and adapt their current programs, to include millions of individuals who may want to pursue their passions and generate a sustainable livelihood in the process. The hunger for "good" work is the new American Dream, shared by both future billionaires and those with more modest ambitions. Let's design programs that help everyone succeed on their own terms.

Additional Search Terms: solo entrepreneurs, selfemployed, sole proprietors, working by myself, being my own boss 